\title{
Local Wisdom of Batak Toba in Supporting Tourism Sector in Regency of Samosir
}

\author{
Dumora Jenny Margaretha Siagian*, Hidayat Hamsari*, Fikarwin Zuska** \\ *Departement of Anthropology \\ State University of Medan \\ ** Departement of Anthropology \\ University of Sumatera Utara \\ Medan, Indonesia \\ Email: jenny79.siagian@gmail.com
}

\begin{abstract}
This study aims to explore and analyze the local wisdom of Batak Toba community that is useful and can support the tourism sector in Samosir regency. Samosir as an island located in the middle of Lake Toba is a leading tourist destination in the area of Lake Toba. As a beautiful island occupied by generally Batak Toba ethnic, Samosir not only has beautiful natural scenery but also has a culture that attracts tourists to learn it. However, Samosir has not become a comfortable tourist destination for tourists, especially for those who initially interested in Batak Toba culture. This research is a qualitative research which explains descriptively local wisdom of Batak Toba community that can be rebuilt to attract tourists to visit Samosir Island. Data collection is done through observation, as well as tracing documents and previous research results. The analysis is done descriptively. The result of the research is that the development of community-based tourism is inseparable from local culture and local wisdom. Batak Toba local wisdom becomes an important potential in shaping the character of Batak people who can socialize with tourists. So that the tourists can be comfortable in the midst of indigenous peoples. So it needs to be revived and re-empowered, in addition to welcoming tourists, also to preserve the local wisdom that has been taught the ancestors to be guided by the next generations. This can be done through education and socialization to schools and community groups around the tourist objects.
\end{abstract}

Keywords: local wisdom; culture; Batak Toba; tourism; Samosir

\section{INTRODUCTION}

The current problems of tourism, not only the lack of development of tourism objects potential, but also the lack of empowerment of local communities to participate in the development of tourism industry in their region. Yet at this time, no doubt, the tourism industry becomes an important opportunity in economic development and improve the livelihoods of people in developing countries. Sarinen and Manwa (2008) ${ }^{1}$ stated that tourism plays a role in improving and fostering the economy of the community. In addition to economic aspects, tourism development also needs to pay attention to aspects of nature conservation and local communities ${ }^{2}$.

In the principle of continues tourism development, proposed a strategy of tourism development planning that oriented to community empowerment by prioritizing the

\footnotetext{
${ }^{1}$ J. Saarinen and H. Manwa, Tourism As A Socio-Cultural Encounter: Host-Guest Relations In Tourism Development In Botswana, Botswana Notes And Records, Vol. 39, (Tourism As A Sustainable Development Factor, pp. 43-53, 2008.

${ }^{2}$ C. Fandeli, Pengusahaan Ekowisata, Penerbit Fakultas Kehutanan UGM, 2000 .
}

role and participation of local communities in a wise and prudent, known as the CommunityBased Tourism Development (CBT). Sunaryo $(2013)^{3}$ said that the concept of CBT is one of the important ideas in the development of modern tourism based on the uniqueness of local communities. This means that the main driving force of tourism activity is the resources and uniqueness of local communities, both physical and nonphysical (traditions or cultures). So that tourism should be seen as an activity based on local community or commonly called as local wisdom-based of the local community.

Today, locality attractiveness is important in appealing tourists to visit a tourist object, due to the boredom of the mass culture brought about by global capitalism. Globalization is the reason for the revival of local culture in various parts of the world 4 . Many tourist objects are packed based on local resources and local wisdom of local community into a well-known object and

${ }^{3}$ B. Sunaryo, Kebijakan Pembangunan Destinasi Pariwisata Konsep Dan Aplikasinya Indonesia, Yogyakarta: Gava Media, 2013.

${ }^{4}$ A. Giddens, Runaway world: Bagaimana Globalisasi Merombak Kehidupan Kita, Jakarta: Gramedia, 2001. 
cultivate the desire of tourists to return to the place, such as in Indonesia there are Yogyakarta, Tanah Toraja, Bali, etc.

Indonesia, which is an archipelago country, has cultural potential spread across the archipelago of Indonesia. With the diversity of culture owned, Indonesia should be able to take advantage of these opportunities to develop tourism based on local wisdom. Local wisdom in anthropological discipline is also known as a local genius.

Local wisdom itself is a set of knowledge along with certain values and norms derived from the adaptation and life experience of a community group in a particular location which then provides a form of thought patterns and certain actions as a way to live in harmony with the environment, with each other, and with themselves ${ }^{5}$. Local wisdom can be tangible (textual, architectural, traditional artwork) and intangible (value system, chanting, advice). However, when viewed from its kind, local wisdom consists of specific governance, value systems, procedures, and provisions such as sensitive areas and sacred areas/buildings ${ }^{6}$.

According to Walker and Diana $(1996)^{7}$, the use of local wisdom in the development of tourism can provide benefits in the economic, physical, and socio-cultural fields in local locations, namely:

1. the economy, including the availability of employment opportunities, the creation of employment diversity, as well as the increase in incomes of residents and regions;

2. physical environment, including maintaining historic buildings and cultural/natural heirlooms, creating infrastructure improvements, increasing efforts to conserve flora fauna and its ecosystem; and

3. socio-culture, including the creation of efforts to preserve local cultural values, increase the pride of citizens, increased opportunities for higher education, and help people to understand themselves (who, where, and uniqueness owned).

${ }^{5}$ I. Djajadi, Kearifan Ilmiah \& Kearifan Lokal: Pedoman Bagi Perumusan Kearifan Lokal Kalbar, Kongres Kebudayaan Kalimantan Barat II, 2010

${ }^{6}$ TOS.Aulia And AH.Dharmawan, Kearifan Lokal Dalam Pengelolaan Sumberdaya Air Di Kampung Kuta, Jurnal Trans Disiplin Sosiologi, Komunikasi, dan Ekologi Manusia, vol. 4, no. 3, 2010.

7 L. Walker and B. Diana, The Tourism Action Society In The Kootenays: Step By Step Guide To Heritage Tourism Development In The Kootenay-Boundary, Kootenay, 1996.
Samosir is one of the regencies in North Sumatra Province located in the middle of Lake Toba. While Lake Toba is one of the world's famous vulkanik lake with its great eruption history about 75,000 years ago. Currently, Lake Toba becomes one of 10 (ten) leading tourism destinations in Indonesia. As a region believed to be the origin of ethnic Batak, in addition to having natural wealth naturally, Samosir also has a cultural richness inherited from the ancestors and a source of interest for people who live outside Samosir.

This cultural treasure that needs to be explored, conserved and developed to attract tourists to visit the island of Samosir. Because cultural tourism is the most popular tourist type in our country. Evidence has shown that this kind of tourism is the main choice for foreign tourists who want to know our culture and art and everything related to the customs and life of our cultural arts $^{8}$. Munawaroh (1999) ${ }^{9}$ also states that in a cultural perspective, tourism activities stimulate the growth of cultural art creations that can be introduced to tourists.

Such is the importance of culture in the life of society and developing tourism, so that culture, including local wisdom, needs to be explored, developed, and even preserved. The study was conducted to explore and analyze the local wisdom of Batak Toba community that is useful and able to support tourism sector in Samosir regency.

\section{METHODOLOGY}

This research is descriptive with a qualitative approach which depicts local wisdom of Toba Batak society. The scope of this research is only on intangible local wisdom (value, advice, chant) that can be utilized in supporting the tourism sector. This research was conducted at Batak Toba Community in Samosir District. The data was collected by searching documents, in the form of books about Batak Toba, Batak Toba history, previous research, and journal, as well as an observation on the life of Batak Toba community in Samosir District. The data obtained will be analyzed by qualitative descriptively describing intangible local wisdom that develops in society and can support tourism.

${ }^{8}$ Pendit, Ilmu Pariwisata: Sebuah Pengantar Perdana, Jakarta: Pradnya Paramita, 2006

9 P. Munawaroh, Peranan Kebudayaan Daerah Dalam Perwujudan Masyarakat Industri Pariwisata, Jakarta: Departemen Pendidikan dan Kebudayaan, 1999 


\section{RESULT AND DISCUSSION}

In the midst of globalization and modernization that cause busyness in the daily life of the community, tourism becomes an important drug for relaxation and medicine that refreshes the human body and mind. The human need for tourism, growing various forms of tourist attractions that are managed and packaged to bring convenience to tourists. According to Astina (1999) ${ }^{10}$, Tourism Attractions (TA) can be divided into 4 categories, namely (1) natural tourist destination, (2) cultural tourism destination, (3) transportation tourist destination, and (4) economic tourism destinations.

Culture Tourism Destination (CTD) continues to grow and develop in various places, and become one of the important local community potentials in tourism development. The development of cultural tourism aims to introduce to the world the culture of the people who become their regional identity, preserve the culture, and also to increase the economy of local communities.

One of the local communities cultures that need to be preserved is local wisdom. Sumarmi and Amiruddin (2014) ${ }^{11}$ state that local wisdom is a local knowledge used by local communities to survive in an environment that integrates with belief systems, norms, cultures and is expressed in long-lasting traditions and myths. Local wisdom is also the result of a culture of local wisdom and local intellectuality which contains the values of civilization with the aim of preserving the environment and for the welfare of society.

Joko Sutarso (2012) ${ }^{12}$ in his journal entitled Menggagas Pariwisata Berbasis Budaya dan Kearifan Lokal said that the potential of culture and local wisdom in the field of tourism is still high even become a tendency of tourism potential in the future. Therefore it needs to be initiated the pattern of tourism development based on culture and local wisdom as a more aesthetic tourist attraction (edipeni) and ethical (adiluhung).

Today, much local wisdom has begun to be forgotten, eroded by the age and foreign culture,

10 I. K. Astina, Geografi Pariwisata, Malang: Universitas Negeri Malang, 1999

${ }^{11}$ Sumarmi and Amirudin, Pengelolaan Lingkungan Berbasis Kearifan Lokal, Yogyakarta: Aditya Media, 2014

12 J. Sutarso, Menggagas Pariwisata Berbasis Budaya Dan Kearifan Lokal, Program Studi Ilmu Komunikasi FKI UMS, 2012 even almost extinct, not least the culture and local wisdom of Batak Toba society. Whereas the local wisdom becomes a superior potential that can be empowered by local people in attracting tourists to visit their region.

Batak Toba community is one of the big tribe which is well known in Indonesia. According to their family tree, Batak people came from Pusuk Buhit in Samosir and spread all over the area to where there are now Batak villages called Bona Pasogit. The Batak Toba community has a strong cultural system and unity. Wherever they are, they are still trying to maintain and live the customs and cultures inherited from their ancestors, including the local wisdom that has been taught to them. In everyday life, Batak Toba people are dependent heavily on the main moral rules of local wisdom to achieve happiness.

Batak Toba community from the beginning has been equipped with a very large adaptation capability, so they can wander wherever and socialize with local communities in the overseas. This can be seen from one of the local wisdom made by Raja Batak and his queen to be guided by his people. The Local wisdom is called Hatopan/ PassaUluan/Pancauluan or five basic words, namely:

\section{Pangintubu do ahu, painundun halak do}

Pantun hangoluan, tois hamagoan

Didia pansur, disi do paridian

Didia solup, disi do parsuhatan

\section{Ditoru tangan na mangido}

This Hatopan has the understanding that every Batak Toba community must have polite and friendly behavior to obtain a peaceful life (pantun hangoluan). If they behave indifferently to people, it will receive disaster (tois hamagoan). Hatopan also teaches that the Batak Toba community must be smart to adapt to the environment (Didia pansur, disi do paridian and Didia solup, disi do parsuhatan) and has a humble nature (Ditoru tangan na mangido).

Other local wisdom derived from observation at the research site is the concept and value of Dalihan Na Tolu or Tungku Nan Tiga. This value serves as a guide that regulates, controls and gives direction to the behavior and deeds (attitude or pattern of action) of Batak Toba people. The concept of Dalihan $\mathrm{Na}$ Tolu is: "Somba Marhula-hula, Manat Mardongan Tubu, and Elek Marboru", which symbolizes the rules of interaction relationships, as well as the basis of 
behavioral patterns towards human beings that become a culture, identity, and civilization inherited by the ancestors (King of Batak) to the next generations, are neatly arranged.

The value contained in Dalihan Na Tolu is Hula-hula (The name for the family of the wife) we must respect $(S o m b a)$ in order to always get the blessing, safety, and welfare. Dongan tubu (friends/relatives) should we appreciate (Manat), be careful, keep the brotherly ethics in order to avoid all disputes. And Elek Marboru (always loving a sister) for peace and blessing always overshadows her own family.

Because of the importance of this concept, the value contained in Dalihan $\mathrm{Na}$ Tolu is made a living order and a source of motivation to behave. According to Harahap and Siahaan (1987) ${ }^{13}$, the Batak Toba people live Dalihan $\mathrm{Na}$ Tolu as a cultural value system that provides guidelines for orientation, perception, and definition of reality. The concept and value contained in Dalihan Na Tolu are still guided by the Batak Toba community up to now. This can be seen in every custom event or in the community of Batak Toba.

Armaidy Armawi (2008) ${ }^{14}$ in his article entitled Kearifan Lokal Batak Toba Dalihan Na Tolu Dan Good Governance Dalam Birokrasi Publik, stated that Dalihan Na Tolu Culture regulates and controls the life of Batak Toba not only in the context of tradition bonds but also in the field of economy, religion, politics, even bureaucracy. This value should also be used in communicating and welcoming tourists. Tourists are considered hula - hula, dongan tubu, and boru that must be respected, appreciated, and cherished. If there is such an assumption in the Batak Toba community, Batak land like Samosir will be a safe and friendly place for tourists and they can feel at home.

The other local wisdom of Batak Toba is 'bohi ni huta- dalan, bohi ni jabu - alaman.' This means that the importance of maintaining cleanliness for the Batak Toba community, both environmental hygiene and also the cleanliness of the house itself. Based on observations made in tourist objects in Samosir District, now these guidelines are no longer done Batak Toba people. In fact, at this time, Batak Toba people are known

\footnotetext{
13 H. B. Harahap and Hotman M. Siahaan, Orientasi Nilai - Nilai Budaya Batak, Jakarta: Sanggar Willem Iskandar, 1987.

14 A. Armawi, Kearifan Lokal Batak Toba Dalihan Natolu Dan Good Governance Dalam Birokrasi Publik, Jurnal Filsafat, vol. 18, no. 2, Agustus 2008
}

with their dirty. Though they already have a philosophy of life that comes from his ancestors, it has begun to fade. Therefore it is important to revive the philosophy so that the Batak Toba people can maintain the cleanliness of the environment, especially the cleanliness of tourist objects to make tourists comfortable enjoying the place for a long time.

In relation to tourism, Toba Batak society should be able to use local wisdom in the tourism objects. If the Batak Toba community preserves Hatopan, Dalihan Na Tolu concept and other philosophy in adapting and communicating with tourists, then the tourists will be able to feel comfortable. People's views on the image of Batak community can change, no longer said to be rude, but become a Batak community is polite.

The whole order of custom and cultural values is actually considered sacred by the Batak Toba people. It is also revealed in the traditional advice they get from their ancestors, namely 'martagan sipiliton, maransimun so bolaon, adatni ama dohot ompu tokka siuban.' The value contained in this custom advice suggests the existence of one obedience to the ancestors that the customs that have been inherited by the true ancestor cannot be changed. So should the existing local wisdom is revitalized to form the character of Batak Toba community as taught by the ancestors.

The presumption that local wisdom has sacred value in building social relationships for life must be preserved and implemented. Because there are the Batak Toba people who say 'omputta na di jolo martungkot sialagundi, adat na pinukka ni parjolo ingkon ihuthonon ni parpudi,' which means what has become the cultural heritage of the ancestors will be preserved and continued the next generation.

However, in this era of globalization, there is a shift in the orientation of Batak people, that customs and culture are old, no need to be led again. From the observations made, often local wisdom is only guided when there are customary events only. However, in everyday life, Batak Toba society has begun to change and does not practice the local wisdom. Can be seen, especially when welcoming and serving tourists, Batak people are more concerned with the benefits gained from tourists, rather than thinking how to make tourists feel comfortable and want to return to their area.

When conducted observations in Tomok area, Batak people who become business actors 
there no longer have the patience and politeness in serving tourists. Many become angry, for example, if the merchandise is only held and not so purchased by tourists. Seen also Batak community no longer do humble behavior as taught by the ancestors. Batak Toba society has not made Dalihan Na Tolu in touch with tourists.

Therefore, the Batak Toba community needs to be reminded of the value and local wisdom that their ancestors have inherited, to form the character of Batak Toba people favored by tourists. This can be done through education in schools. Students are taught to guide and practice the local wisdom in the school environment initially, which later he will have a character that can be a role model in the home and community environment. Through community groups, such as the youth group and the tourism conscious group, through socialization and invitations to practice their own local wisdom in welcoming tourists.

Local wisdom becomes one of the important assets of local communities that can be empowered in the tourism sector. Joko Sutarso $(2012)^{15}$ said that the development of tourism in a region should provide a sense of security for the tourists because the residents and their creativity are interesting and exotic tourism object. The hospitality of the inhabitants is a tourist attraction owned by the Indonesian people, as well as the life of the community when interacting with nature and god is a tourism attraction that captivates the heart.

Samosir regency as one of the leading tourist destinations (TD) in North Sumatra should be able to capture it and do community empowerment through the revitalization of local wisdom. Because the Batak Toba community has a wealth of culture and local wisdom, so it should be able to form the character of Batak people who are liked by outsiders. That way, many tourists will be interested to come to see and learn about the culture and local wisdom of Batak Toba community in Samosir regency.

\section{CONCLUSION}

The development of community-based tourism is inseparable from local culture and local wisdom. Batak Toba local wisdom becomes an important potential in shaping the character of Batak people who can socialize with tourists. So that the tourists can be comfortable in the

15 J. Sutarso, Menggagas Pariwisata Berbasis Budaya Dan Kearifan Lokal, Program Studi Ilmu Komunikasi FKI UMS, 2012 midst of indigenous peoples. So it needs to be revived and re-empowered, in addition to welcoming tourists, also to preserve the local wisdom that has been taught the ancestors to be guided by the next generations. This can be done through education and socialization to schools and community groups around the tourist objects.

\section{ACKNOWLEDGMENT}

The authors would like to thank the graduate program of Medan State University, especially the lecturers of Post-Graduate of Social Anthropology, who provide opportunities to gain knowledge and facilitate the formation of this paper.

\section{REFERENCES}

Armawi, Kearifan Lokal Batak Toba Dalihan Natolu Dan Good Governance Dalam Birokrasi Publik, Jurnal Filsafat, vol. 18, no. 2, Agustus 2008.

Giddens, Runaway World: Bagaimana Globalisasi Merombak Kehidupan Kita, Jakarta: Gramedia, 2001.

Sunaryo, Kebijakan Pembangunan Destinasi Pariwisata Konsep Dan Aplikasinya Indonesia, Yogyakarta: Gava Media, 2013.

Fandeli, Pengusahaan Ekowisata, Penerbit Fakultas Kehutanan UGM, 2000.

Drs. N. Siahaan, Adat Dalihan Natolu (Prinsip Dan Pelaksanaanya), Jakarta: Grafina, 1982.

Suwantoro, Dasar-Dasar Pariwisata, Edisi Pertama, Cetakan Pertama, Yogyakarta: PenerbitAndi, 1997.

B. Harahap and Hotman M. Siahaan, Orientasi Nilai - Nilai Budaya Batak, Jakarta: Sanggar Willem Iskandar, 1987.

Djajadi, Kearifan Ilmiah \& Kearifan Lokal: Pedoman Bagi Perumusan Kearifan Lokal Kalbar, Kongres Kebudayaan Kalimantan Barat II, 2010.

K. Astina, Geografi Pariwisata, Malang: Universitas Negeri Malang, 1999.

Saarinen and H. Manwa, Tourism As A SocioCultural Encounter: Host-Guest Relations In Tourism Development in Botswana, Botswana Notes and Records, vol. 39, (Tourism As A Sustainable Development Factor), pp. 43-53, 2008. 
Sutarso, Menggagas Pariwisata Berbasis Budaya Dan Kearifan Lokal, Program Studi Ilmu Komunikasi FKI UMS, 2012.

Kontjaraningrat, Manusia Dan Kebudayaan di Indonesia. Jakarta: Djambatan, 1974.

Walker and B. Diana, The Tourism Action Society In The Kootenays: Step By Step Guide To Heritage Tourism Development In The Kootenay-Boundary, Kootenay, 1996.

Pendit, Ilmu Pariwisata: Sebuah Pengantar Perdana, Jakarta: Pradnya Paramita, 2006.
Munawaroh, Peranan Kebudayaan Daerah Dalam Perwujudan Masyarakat Industri Pariwisata, Jakarta: Departemen Pendidikan dan Kebudayaan, 1999.

Sumarmi and Amirudin, Pengelolaan Lingkungan Berbasis Kearifan Lokal, Yogyakarta: Aditya Media, 2014.

TOS. Aulia and AH. Dharmawan, Kearifan Lokal Dalam Pengelolaan Sumberdaya Air di Kampung Kuta, Jurnal Trans Disiplin Sosiologi, Komunikasi, dan Ekologi Manusia, vol. 4, no. 3, 2010. 